\title{
The impact of IUGR on pancreatic islet development and $\beta$-cell function
}

\section{Brit H Boehmer', Sean W Limesand ${ }^{2}$ and Paul J Rozance ${ }^{1}$}

1Department of Pediatrics, Perinatal Research Center, University of Colorado School of Medicine, Aurora, Colorado, USA

${ }^{2}$ School of Animal and Comparative Biomedical Sciences, University of Arizona, Tucson, Arizona, USA
Correspondence should be addressed to P J Rozance

Email

paul.rozance@ucdenver.edu

\begin{abstract}
Placental insufficiency is a primary cause of intrauterine growth restriction (IUGR).

IUGR increases the risk of developing type 2 diabetes mellitus (T2DM) throughout life, which indicates that insults from placental insufficiency impair $\beta$-cell development during the perinatal period because $\beta$-cells have a central role in the regulation of glucose tolerance. The severely IUGR fetal pancreas is characterized by smaller islets, less $\beta$-cells, and lower insulin secretion. Because of the important associations among impaired islet growth, $\beta$-cell dysfunction, impaired fetal growth, and the propensity for T2DM, significant progress has been made in understanding the pathophysiology of IUGR and programing events in the fetal endocrine pancreas. Animal models of IUGR replicate many of the observations in severe cases of human IUGR and allow us to refine our understanding of the pathophysiology of developmental and functional defects in islet from IUGR fetuses. Almost all models demonstrate a phenotype of progressive loss of $\beta$-cell mass and impaired $\beta$-cell function. This review will first provide evidence of impaired human islet development and $\beta$-cell function associated with IUGR and the impact on glucose homeostasis including the development of glucose intolerance and diabetes in adulthood. We then discuss evidence for the mechanisms regulating $\beta$-cell mass and insulin secretion in the IUGR fetus, including the role of hypoxia, catecholamines, nutrients, growth factors, and pancreatic vascularity. We focus on recent evidence from experimental interventions in established models of IUGR to understand better the pathophysiological mechanisms linking placental insufficiency with impaired islet development and $\beta$-cell function.
\end{abstract}

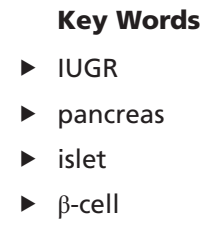

Journal of Endocrinology (2017) 235, R63-R76

\section{Introduction}

Intrauterine growth restriction (IUGR) is defined as the failure of a fetus to achieve its genetic potential for size. Placental insufficiency is a leading cause of IUGR in humans and complicates $4-8 \%$ of pregnancies (Hendrix \& Berghella 2008, Platz \& Newman 2008). The definition of IUGR contrasts with that for small-forgestational-age infants (SGA), who are typically defined as having birth weights below the 10th percentile, though other definitions have been employed. Essentially, the definition of IUGR differs from SGA in that it refers to a pathophysiological process as opposed to a statistically derived definition. The differences in terminology and definitions has introduced heterogeneity into human studies (Crovetto et al. 2016), but most studies have identified a higher risk for perinatal mortality and short and long term morbidities in IUGR and SGA newborns 
(von Beckerath et al. 2013). This includes an increased risk of developing type 2 diabetes mellitus as they age (T2DM; Hales \& Barker 2001).

Reduced nutrient and oxygen transport to the fetus are hallmarks of placental insufficiency and are caused by lower placental mass (Regnault et al. 2002b, Marconi et al. 2006), abnormal placental structure (Mayhew et al. 2003, Sibley et al. 2005), and decreased glucose and amino acid transporter abundance and activity (Economides et al. 1989, Cetin et al. 1990, Jansson et al. 1998, Paolini et al. 2001, Cetin 2003, Platz \& Newman 2008). These placental defects lead to hypoxemic and hypoglycemic fetuses with resulting higher circulating catecholamine concentrations and lower circulating insulin concentrations (Greenough et al. 1990, Nicolini et al. 1990). IUGR fetuses also are characterized by impaired glucose stimulated insulin secretion (GSIS; Nicolini et al. 1990). In cases of severe IUGR, fetuses have smaller and less vascularized pancreatic islets with fewer $\beta$-cells (Van Assche et al. 1977). This contrasts to cases of less severe IUGR in which structural pancreatic defects are less pronounced (Béringue et al. 2002). These data indicate that the degree of impaired islet development may correlate with the severity of placental insufficiency, a phenomenon observed in animal models of placental insufficiency (Limesand et al. 2005, 2006, Gatford et al. 2008, Rozance et al. 2009b). These findings also show that reduced insulin secretion in IUGR fetuses is not solely due to smaller islets and less $\beta$-cells.

The relationship between fetal plasma insulin concentrations and fetal growth is critical. In addition to regulating glucose metabolism (Hay et al. 1988), insulin produced by the fetuses also promotes their systemic growth (Fowden et al. 1989). Thus, the fetal $\beta$-cell links fetal nutrient supply with fetal nutrient metabolism and anabolic signals for growth. The $\beta$-cell defects in IUGR are even more important when one realizes that T2DM is characterized by the combination of tissue insulin resistance and insufficient insulin secretion (Barker et al. 1993, Hales \& Barker 2001, Kasuga 2006). Interestingly, children and adults that were formerly SGA fetuses develop insulin resistance (Jensen et al. 2002, Mericq et al. 2005, Mathai et al. 2012, Milovanovic et al. 2014). Insulin sensitivity is lower in adults born SGA and experiencing catch up growth compared to adults born appropriate for gestational age (AGA) or SGA without compensatory growth (Forsén et al. 2000, Fabricius-Bjerre et al. 2011, Kajantie et al. 2015). Several studies also report impaired $\beta$-cell function, which persists throughout life
(Cook et al. 1993, Crowther et al. 2000, Jensen et al. 2002, Bazaes et al. 2003, Setia et al. 2006). Therefore, the greater risk for developing T2DM in formerly IUGR and SGA individuals is due to a combination of both an increased risk of insulin resistance and an increased risk of impaired $\beta$-cell development and function. The mechanisms by which IUGR impair $\beta$-cell development and function is the focus of this review.

Due to ethical considerations, evaluation of pancreatic islet development and function in human IUGR other than the basic observations noted above are limited. As a result, animal models are used to investigate the mechanistic link between placental insufficiency and the endocrine pancreas phenotype (Green et al. 2010). Similar to IUGR humans, animal models of placental insufficiency and IUGR are characterized by progressive islet and $\beta$-cell dysfunction, impaired glucose tolerance, and a propensity to develop T2DM (Green et al. 2010). In this review, we focus on recent studies with animal models of IUGR in which interventional experiments have manipulated the fetal and/or neonatal environment following established placental insufficiency and/or IUGR to further our understanding of the mechanisms linking placental insufficiency with $\beta$-cell dysfunction and impaired islet development and function.

\section{Animal models of IUGR with $\beta$-cell dysfunction}

\section{Rodent models}

Rodent models of placental insufficiency and IUGR are valuable for determining the adulthood pathogenesis of diabetes and the intergenerational impacts due to their short lifespan and generation interval. Three welldefined rat models of IUGR show impaired pancreatic islet development, establish lasting effects in adults, and have been subjected to experimental perinatal interventions to better define the mechanisms leading to diminished islet development and function. Uterine artery ligation (UAL) at embryonic day (E) 18-19 causes an acute decrease in fetal nutrients and oxygen near term (E22), and results in a 10-20\% reduction in body weight (Wigglesworth 1964, Ogata et al. 1986, Siebel et al. 2010, Delghingaro-Augusto et al. 2014, Ikeda et al. 2016). Maternal dietary restrictions also are widely utilized in rodents to induced IUGR. Specifically, IUGR is produced when dams are fed an isocaloric diet with low protein (LP; generally $40-50 \%$ relative to controls) 
throughout gestation (Snoeck et al. 1990, Boujendar et al. 2002, Zhang et al. 2016). Reductions in fetal weight are observed as early as E14 (Zhang et al. 2016). IUGR also is produced when maternal caloric intake is reduced by $50 \%$ during the last week of gestation and results in a 12-20\% reduction in offspring birth weight (CR; Woodall et al. 1996, Garofano et al. 1997, 1998). Observations in these models demonstrate a strong connection between in utero fetal undernutrition with impaired pancreatic islet development and progressive $\beta$-cell dysfunction which can be evident at or before birth and persist into maturity leading to glucose intolerance and T2DM.

\section{Sheep models}

In fetal sheep, $\beta$-cell responsiveness to glucose develops during the second half of gestation, paralleling the fetal glucose responsiveness observed in human pregnancies (Nicolini et al. 1990, Molina et al. 1993, Aldoretta \& Hay 1999). Due to the accessibility of the fetal vasculature for chronic catheterization, sheep models of placental insufficiency and IUGR allow for testing mechanisms that link in utero conditions of IUGR, impaired islet development and $\beta$-cell dysfunction. Placental insufficiency occurs when pregnant sheep are exposed to elevated ambient temperatures in mid to late gestation. Experimental replication of this naturally occurring phenomenon in sheep (PI-IUGR) results in a progressive reduction in the capacity for nutrient and oxygen transport to the fetus resulting in IUGR (Bell et al. 1987, Regnault et al. 2002a). Near term ( $90 \%$ of gestation to term), placental and fetal weights are reduced by $\sim 40 \%$ (Galan et al. 1999, de Vrijer et al. 2004, Limesand et al. 2006). Alternatively, the cotyledonary placenta, unique to ruminants, can be experimentally manipulated by the surgical removal of most of the uterine caruncles prior to pregnancy to induce placental restriction and IUGR (UC-PI; Robinson et al. 1979). Similar to the PI-IUGR model, the placental restriction resulting from carunclectomy lowers the supply of nutrients and oxygen to the fetus, resulting in a $20 \%$ decrease in body weight near term compared with controls (Mellor et al. 1977, Robinson et al. 1979, Owens et al. 2007). Comparing data from both of these models provides the opportunity to see a spectrum of fetal outcomes based perhaps on the severity of placental insufficiency and IUGR. The sheep models of IUGR are advantageous in that decrements in placental nutrient and oxygen supply to the fetus can be quantified and in vivo fetal experimental interventions can be performed. Following these interventions fetal glucose tolerance tests and in vitro islet functional assays can be combined with structural analysis of the pancreas to determine which specific nutrients or hormones are limiting for islet development and function.

\section{Pancreatic development}

Relationships between IUGR and pancreatic $\beta$-cell function must be interpreted within the context of pancreatic development. Although fetal sheep more closely mimic humans in the overlapping developmental transitions of the pancreas and islets, the distinct developmental transitions in rodent models allow investigators to elucidate the specificity of the developmental stages in their response to insults or interventions. Important transitional periods and developmental adaptations in the pancreas of IUGR animals have been recently reviewed (Green et al. 2010, Conrad et al. 2014, Jennings et al. 2015, Willmann et al. 2016). Briefly, the primary transition of the endoderm begins at embryonic day (E) 11 in rats, before 24 days gestational age (dGA) in sheep, and 25-26dGA in humans (term gestation is E22, $147 \mathrm{dGA}$, and 40 weeks of gestational age for the rat, sheep, and human, respectively). Initiation of the secondary transition in the fetal rat occurs at E15-18 with the identification of mature secretory products and is followed by isletogenesis (E17-21) and endocrine cell proliferation (E21.5-22). The secondary transition, isletogenesis, and endocrine cell proliferation in sheep and humans occurs over a broad period during gestation (approximately $20 \%$ of gestation to term).

\section{Reduced insulin secretion and pancreatic dysfunction in the IUGR fetus}

Lower insulin secretion, smaller islets, lower islet density, less $\beta$-cells, and decreased pancreatic weight and insulin content are hallmarks of the IUGR fetal pancreas in the various animal models (Green et al. 2010, Abuzgaia et al. 2015). Defects in $\beta$-cell replication and expression of genes regulating $\beta$-cell proliferation, apoptosis, and neogenesis all contribute to reduced $\beta$-cell mass to varying extents in the different models (Petrik et al. 1999, Limesand et al. 2005, Dumortier et al. 2007, Kelly et al. 2017). In PI-IUGR fetal sheep, basal insulin concentrations and glucose-stimulated insulin secretion (GSIS) were lower than controls at both $70 \%$ and $90 \%$ of gestation (Limesand et al. 2006, 2013).
๑ 2017 Society for Endocrinology Printed in Great Britain
Published by Bioscientifica Ltd. 
Additionally, the insulin content of the islets isolated from near term IUGR fetuses was $\sim 80 \%$ lower than control islets. Despite this, the IUGR islets secreted a higher proportion of their insulin in response to glucose and other secretagogues, which likely relates to increased expression of genes responsible for much of the stimulus-secretion coupling in the islets (Limesand et al. 2006, Kelly et al. 2017). In contrast to the severe insulin secretion defects observed in the PI-IUGR model, insulin secretion was not reduced in fetuses following uterine carunclectomy when compared to controls. However, insulin secretion was inversely correlated with factors associated with placental insufficiency like fetal weight and blood oxygen concentrations (Owens et al. 2007). Importantly, the subtle fetal insulin secretion defects in the carunclectomy model of placental insufficiency were progressive as insulin secretion was reduced in one month old post carunclectomy lambs (De Blasio et al. 2007). Although a compensatory increase in $\beta$-cell mass occurred into adulthood, insulin secretion of UC-PI sheep remained insufficient relative to progressive declines in insulin sensitivity (Gatford et al. 2008), findings which are similar to formerly SGA humans (Cook et al. 1993). Progressive insulin secretory defects are also identified in CR, LP, and UAL rat models (Garofano et al. 1997, 1999, Simmons et al. 2001, Fernandez-Twinn et al. 2005, Dumortier et al. 2007).

\section{Perinatal interventions to determine the mechanisms of pancreatic islet dysfunction in IUGR}

\section{Nutrient regulation of $\beta$-cells}

Glucose The $\beta$-cell functions to link carbohydrate, amino acid, and lipid metabolism to insulin secretion (Newsholme et al. 2014). In the fetus, this results in a situation in which the $\beta$-cell acts as a sensor of the fetal nutrient supply from the placenta and can link this supply to appropriate production of fetal growth factors (Gleason et al. 2007, Brown et al. 2011, Newsholme et al. 2014). The ability of nutrients to stimulate insulin secretion largely depends on the ability of the $\beta$-cell to utilize the nutrient as a fuel source (Malaisse et al. 1979). Glucose, the primary insulin secretagogue, is metabolized through glycolysis and the tricarboxylic acid (TCA) cycle stimulating ATP production, elevating the cytosolic ATP/ADP ratio causing $\beta$-cell membrane depolarization, increased cytosolic calcium concentrations and insulin secretion (Henquin 2000, Wiederkehr \& Wollheim 2012). Furthermore, metabolism of glucose also leads to the generation of many different secondary messengers that also stimulate insulin secretion (German 1993, Gleason et al. 2007, Cline et al. 2011, Spégel et al. 2011, Huang \& Joseph 2012, Göhring et al. 2014, Patel et al. 2014, Andersson et al. 2015). Given the role of $\beta$-cell nutrient stimulation-insulin secretion coupling in the fetus for the regulation of growth, multiple studies of the IUGR fetal $\beta$-cell and pancreatic function have focused on manipulation of fetal nutrient concentrations and supply.

We have utilized chronic maternal insulin infusions to test the effects of reduced fetal glucose supply on $\beta$-cell function independent of lower placental capacity to transport amino acids or oxygen to the fetus (Fig. 1). Maternal insulin infusions markedly decrease transfer of glucose to the fetus, fetal plasma glucose concentrations, and fetal weight. Because insulin does not cross the placenta, fetal insulin concentrations also are markedly reduced (17\%; DiGiacomo \& Hay 1990, Limesand \& Hay 2003, Rozance et al. 2006). Additionally, the insulin secretory response of hypoglycemic fetuses and their isolated islets to glucose and amino acids is diminished

\section{Placental glucose transfer}

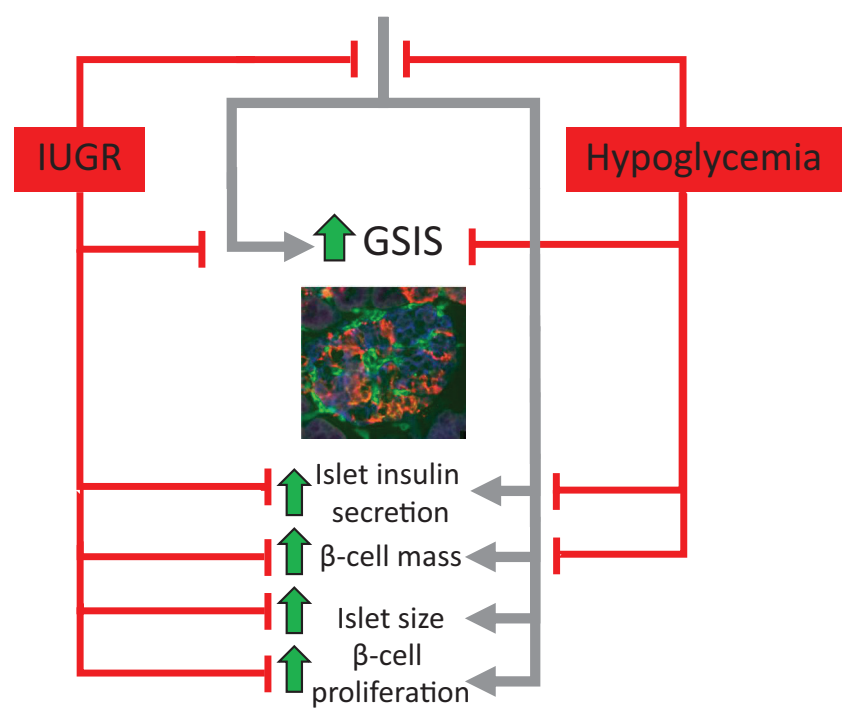

Figure 1

A schematic representation of fetal pancreatic and $\beta$-cell dysfunction in models of IUGR and potential mechanisms of glucose regulation for $\beta$-cell dysfunction. The fetal pancreas response to glucose is represented by the gray lines. Pancreatic dysfunctions associated with models of IUGR are depicted by red lines. A fetal sheep islet is at $90 \%$ of gestation is depicted in the micrograph and has been immunostained for insulin ( $\beta$-cell; blue), glucagon + somatostatin + pancreatic polypeptide (red), and vasculature (GS1; green).
(๑) 2017 Society for Endocrinology Printed in Great Britain 
despite similar numbers of pancreatic $\beta$-cells in control and hypoglycemic fetuses following two weeks of maternal insulin treatment near term (Limesand \& Hay 2003, Rozance \& Hay 2006, Rozance et al. 2006, 2007). Importantly, when glucose concentrations were returned to normal for five days, fetal insulin concentrations also returned to normal but insulin secretory defects did not fully recover showing programming of fetal $\beta$-cell function with even short duration nutrient deprivation (Limesand \& Hay 2003). When we extended this experimental paradigm from two weeks to eight weeks, beginning at approximately $50 \%$ of gestation, the hypoglycemic fetuses show a similar attenuation of GSIS (Lavezzi et al. 2013). $\beta$-cell mass, however, was significantly lower in these hypoglycemic fetuses compared to controls, thus showing that chronic experimental fetal hypoglycemia can mimic the two main pancreatic islet defects seen in IUGR fetuses, attenuated GSIS and lower $\beta$-cell mass (Nicolini et al. 1990, Van Assche et al. 1977, Lavezzi et al. 2013).

Having demonstrated that experimental fetal hypoglycemia replicates the major pancreatic islet defects in IUGR, we sought to determine if restoring glucose concentrations to control concentrations would restore fetal insulin secretion and $\beta$-cell mass to normal. Following direct infusions of glucose into PI-IUGR sheep fetuses which were adjusted to increase fetal glucose concentrations to control levels for two weeks, fetuses developed worse hypoxemia, acidosis, and increased norepinephrine concentrations compared to saline infused PI-IUGR fetuses by the end of the study (Rozance et al. 2009b). Not surprisingly, fetal GSIS was also lower than the saline infused PI-IUGR fetuses. Furthermore, there was no impact of the glucose infusion on pancreatic $\beta$-cell mass (Rozance et al. 2009b).

Amino acids Many amino acids stimulate insulin secretion through the above mentioned pathways for glucose metabolism and other, complimentary metabolic pathways (Gao et al. 2003, Doliba et al. 2007, Gleason et al. 2007, Cline et al. 2011, Gadhia et al. 2013). Branched chain amino acids (BCAAs) are especially important for stimulation of $\beta$-cells (Milner 1969, MacDonald et al. 1991, Newsholme et al. 2006). BCAAs are metabolized by branched-chain aminotransferases (e.g. leucine to $\alpha$-ketoisocaproate (KIC)) and the mitochondrial branchedchain $\alpha$-keto acid dehydrogenase complexes (BCKAD) to produce glutamate, C3-acylcarnitine, succinyl-CoA, acetyl-CoA, and acetoacetate, thus providing TCA cycle intermediates which increase the $\beta$-cell ATP/ADP ratio and stimulate insulin secretion (Newgard 2012). In addition, leucine stimulates metabolism of other nutrients by allosterically activating glutamate dehydrogenase to enhance glutaminolysis and anapleurosis (Gao et al. 2003).

The acute stimulatory effect of amino acids on $\beta$-cell insulin secretion has been demonstrated in fetal sheep, both in vivo and in isolated fetal sheep islets in vitro (Molina et al. 1993, Rozance et al. 2006, Brown et al. 2009). Amino acids not only stimulate fetal insulin secretion, but they also potentiate fetal GSIS (Gadhia et al. 2013). In human cases of placental insufficiency and IUGR, amino acid transfer to the fetus is lower than in normally growing fetuses (Cetin et al. 1990, Jansson et al. 1998, Galan et al. 2009, Brown et al. 2012). Lower placental transfer of the BCAA leucine to the fetus is one of the most consistent features of placental insufficiency and IUGR. In fact, one study showed that the size of the decrement in leucine transfer to the IUGR fetus was directly associated with the severity of IUGR in human pregnancies complicated by placental insufficiency (Marconi et al. 1999).

Because of these relationships among placental insufficiency, amino acid transfer to the fetus, and $\beta$-cell function; we performed a series of studies to quantify the impact of amino acid supplementation on fetal insulin secretion, islet structure, and islet function in normally grown and IUGR fetal sheep (Fig. 2). Following a direct fetal infusion of a complete mixture of amino acids enriched in the essential and BCAA, targeting a $25-50 \%$ increase in BCAA concentrations for 10-12 days, fetal insulin concentrations were not different between amino acid- and saline-infused fetuses (Maliszewski et al. 2012, Gadhia et al. 2013). Fetal GSIS, however, almost doubled with amino acid supplementation despite equivalent islet size, numbers of $\beta$-cells, and pancreatic insulin content (Gadhia et al. 2013). In PI-IUGR sheep fetuses, where GSIS and amino acid stimulated insulin secretion were significantly attenuated in vivo, GSIS was enhanced almost to that of control fetuses after eleven days of amino acid supplementation (Brown et al. 2016). We then tested the impact of amino acids on pancreatic structure and insulin secretion from isolated islets from PI-IUGR sheep fetuses. In contrast to pancreatic islets isolated from control fetal sheep, islets from PI-IUGR fetal sheep were not responsive to supplemental amino acids. Importantly, and unlike observations in the amino acid infused control fetuses, pancreatic insulin content, islet size, and $\beta$-cell mass in the amino acid infused PI-IUGR fetuses were significantly greater than in saline infused

Published by Bioscientifica Ltd. 
Amino acids

IUGR

\section{Insulin secretion}
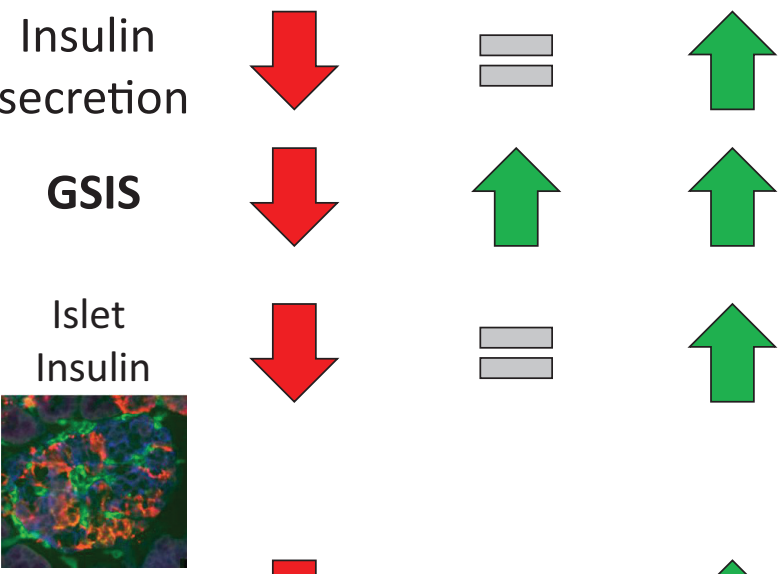

$\beta$-cell

Mass
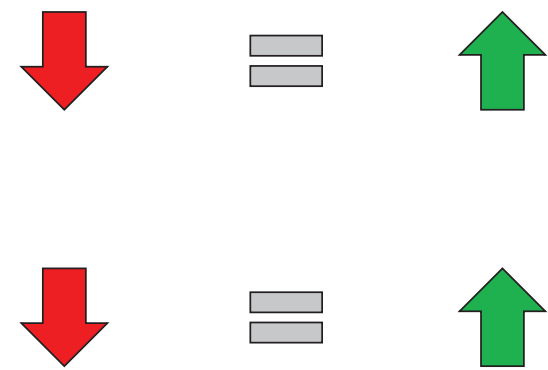

Figure 2

Pancreatic and $\beta$-cell dysfunction in PI-IUGR and the response to increased exogenous amino acid concentrations. A fetal sheep islet is at $90 \%$ of gestation is depicted in the micrograph and has been immunostained for insulin ( $\beta$-cell; blue), glucagon + somatostatin + pancreatic polypeptide (red), and vasculature (GS1; green).

PI-IUGR fetuses (Brown et al. 2016). The enhanced insulin secretion and pancreatic morphology were independent of any differences in glucose, norepinephrine or oxygen concentrations between the groups of IUGR fetuses (Brown et al. 2016).

A consistent finding with both acute and chronic amino acid infusion studies has been increased fetal plasma glucagon concentrations and/or pancreatic glucagon content (Rozance et al. 2009a, Gadhia et al. 2013, Brown et al. 2016). This has led to speculation that in addition to directly increasing $\beta$-cell metabolism and generation of secondary messengers, amino acids may also be potentiating $\beta$-cell function via glucagon dependent mechanisms which include the generation of secondary messengers (Pipeleers et al. 1985, Schuit \& Pipeleers 1985, Huypens et al. 2000). Although generation of secondary messengers in the IUGR $\beta$-cell has not been investigated specifically, there is some evidence suggesting their role in impaired $\beta$-cell function in IUGR fetuses. For example, suppression of Wnt signaling and differential expression of potassium channels and mediators of calcium signaling were observed in the transcriptome of IUGR fetal sheep islets compared with controls (Kelly et al. 2017). It is important to note that second messaging compounds may

influence either nutrient sensing or insulin exocytosis mechanisms and also can link nutrient stimulated insulin secretion to $\beta$-cell proliferation. Thus impaired generation of these secondary messengers could impact both of the main islet phenotypes found in IUGR, decreased insulin secretion and decreased $\beta$-cell mass (Doliba et al. 2007, Gleason et al. 2007, Cline et al. 2011, Erion et al. 2015, Fridlyand \& Philipson 2016).

\section{Hypoxemia, catecholamines and $\beta$-cell dysfunction}

Fetal hypoxemia is a common feature in human and animal models of placental insufficiency that is proposed to have direct and indirect actions that inhibit insulin secretion and is also implicated in the developmental programming of pancreatic islets. Direct effects of oxygen on insulin secretion has been demonstrated in isolated adult rat and canine pancreatic islets (Dionne et al. 1993), but until recently the effects have not been isolated in IUGR fetuses because of the parallel increase in circulating catecholamines seen with hypoxemia (Yates et al. 2012). Surgical procedures to ablate the adrenal medullae of control and PI-IUGR fetal sheep at $65 \%$ and $85 \%$ of gestation were used to separate the effects of hypercatecolinemia and hypoxemia (Yates et al. 2012, Macko et al. 2016). In these studies, we demonstrated that acutely decreased blood oxygen concentrations inhibit GSIS only in presence of an intact adrenal gland, presumably, due to catecholamine secretion. In PI-IUGR fetuses with chronic hypoxemia, GSIS was significantly improved, despite similar blood oxygen content, following ablation of the adrenal medullae compared to the intact, sham operated PI-IUGR fetuses. However, the GSIS was not fully restored to control fetal sheep levels. Acutely increasing fetal oxygen concentrations by maternal tracheal insufflation of humidified oxygen to $100 \%$, significantly increased GSIS in both intact, sham operated and adrenal demedullated IUGR fetuses. The increased GSIS these fetuses were independent of changes in circulating fetal norepinephrine concentrations, demonstrating some inhibition of GSIS by hypoxemia in PI-IUGR fetuses. These studies show that catecholamines and hypoxemia have both dependent and independent roles in suppressing fetal insulin secretion in PI-IUGR (Fig. 3). This conclusion is supported by experiments demonstrating lower GSIS following nine days of fetal anemic hypoxemia (Benjamin et al. 2017).

Pharmacological adrenergic receptor blockade enhanced GSIS in PI-IUGR fetuses at 70\% and 90\% gestation, 


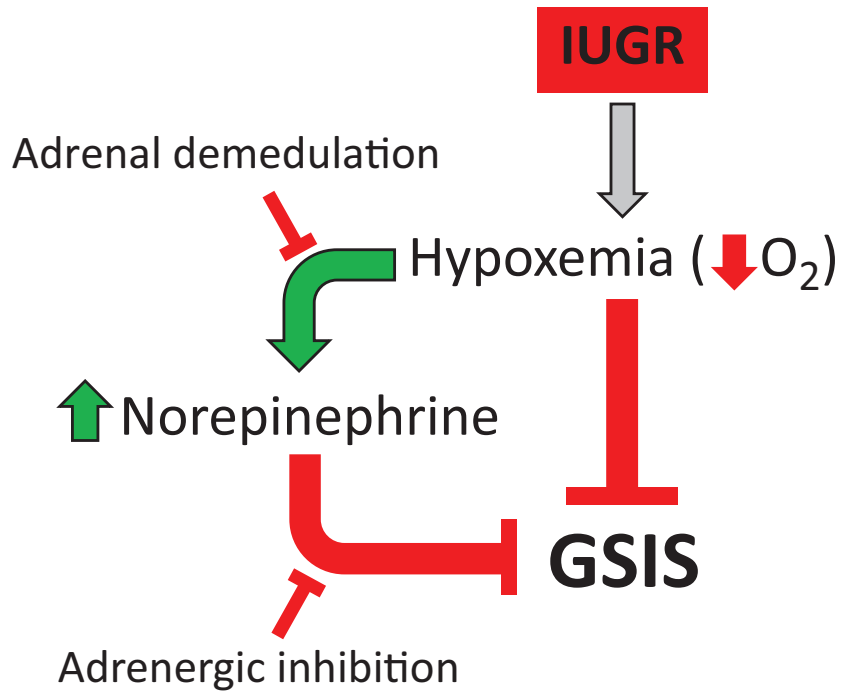

Figure 3

A schematic representation of hypoxic and adrenergic regulation of insulin secretion in PI-IUGR fetuses. Hypoxemia is induced in PI-IUGR and plasma catecholamine concentrations increase to inhibit fetal GSIS. Experimental interventions to disrupt catecholamine signaling are depicted.

providing even more evidence that catecholamines persistently suppress insulin secretion during the second half of gestation (Leos et al. 2010, Macko et al. 2013). In contrast to the adrenal demedullated PI-IUGR fetuses, a compensatory enhancement in GSIS was observed in PI-IUGR fetuses with acute pharmacological inhibition of adrenergic receptors to levels even greater than control fetuses treated with pharmacological adrenergic inhibitor. This was independent of any changes in oxygen content (Leos et al. 2010, Macko et al. 2013). The improved insulin secretion also occurs in fetuses despite lower $\beta$-cell mass, which was shown at both gestation ages (Limesand et al. 2005, 2013). Further evidence for fetal $\beta$-cell hyper-responsiveness to glucose stimulation following inhibition of chronic adrenergic suppression was provided by experiments in near term control fetal sheep following 7-11 days of a chronic fetal insulin infusion where fetal hypoxemia and hypercatecholinemia developed and GSIS was completely attenuated. However, GSIS was completely restored to control levels during acute pharmacological adrenergic inhibition, (Andrews et al. 2015) similar to observations in PI-IUGR fetuses. Recently, we confirmed a direct role for chronically elevated norepinephrine concentrations in the development of $\beta$-cell hyperresponsiveness to glucose stimulation following acute discontinuation of adrenergic signaling. After a seven day infusion of norepinephrine into near term control fetuses was discontinued, a compensatory and persistent increase in GSIS secretion was observed compared to vehicle infused fetuses (Chen et al. 2014, 2017). These experiments are the first to show fetal $\beta$-cell hyper-responsiveness to glucose stimulation following inhibition of chronic adrenergic suppression. Consistent with these in vivo data, IUGR fetal sheep islets at $90 \%$ gestation have higher expression of $\alpha$-adrenergic receptors compared to controls, which likely explains the persistent adrenergic suppression of insulin secretion despite chronic exposure of the islet to high circulating catecholamine concentrations. This may also explain why $\beta$-cells remain defective postnatally because increased expression of $\alpha$-adrenergic receptors can lead to indiscriminant adrenergic signaling in islets (Leos et al. 2010, Rosengren et al. 2010, Macko et al. 2013). Together, these studies show that catecholamines not only have inhibitory effects on insulin secretion in placental insufficiency, but also that as an adaptation to chronic elevations in fetal catecholamine concentrations, the pancreatic $\beta$-cells become hyperresponsive to glucose when the adrenergic inhibition is removed. This phenomenon explains the observation that some previously IUGR fetuses develop features of hyperinsulinism shortly after birth (Collins \& Leonard 1984, Arya et al. 2013, Camacho et al. 2017).

\section{Pancreatic vascularity and paracrine signaling}

Pancreatic vascularity and paracrine signaling between endothelial cells and $\beta$-cells represent another possible mechanism linking placental insufficiency and impaired $\beta$-cell function in IUGR fetuses as depicted in Fig. 4.

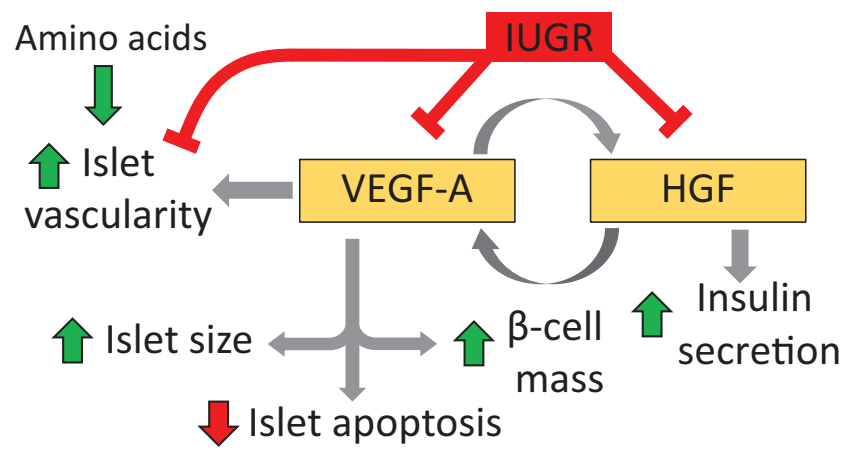

Figure 4

A schematic representation of paracrine signaling between vascular endothelial growth factor A (VEGFA) and hepatocyte growth factor (HGF) in the fetal pancreas. Increased VEGFA enhances endothelial cell HGF, islet size, islet vascularity, and $\beta$-cell mass, and decreases islet apoptosis. Increased HGF increases islet VEGFA and enhances islet insulin secretion. As depicted by the red lines, IUGR decreases expression of islet vascularity and VEFGA, as well as endothelial cell HGF. VEFGA expression is increased with exogenous amino acid supplementation.
๑ 2017 Society for Endocrinology Printed in Great Britain 
Lower pancreatic islet vascularity has been observed in severely growth restricted humans at approximately $80 \%$ of gestation (Van Assche et al. 1977). Similar reductions in pancreatic islet vascularity occur in animal models of IUGR as early as $70 \%$ of gestation (Boujendar et al. 2003, Ham et al. 2009, Rozance et al. 2015). By 90\% of gestation the decrement between control and PI-IUGR fetuses in islet size is greater than at $70 \%$ of gestation, but the vessel density is equivalent (Rozance et al. 2015), suggesting that islet size was limited by vascular supply. Islet expression of the potent angiogenic factor vascular endothelial growth factor A (VEGFA) was decreased at 90\% of gestation, in LP rats (Snoeck et al. 1990, Petrik et al. 1999, Boujendar et al. 2002, Dumortier et al. 2007), UAL rats (Ham et al. 2009), and PI-IUGR sheep. Although VEGFA expression is critical in in islet development, VEGFA inactivation in adult mice islets results in decreased islet vascularity but only slightly impaired glucose metabolism and insulin secretion (Reinert et al. 2013).

Decreased islet vascularity has important implications for $\beta$-cell function because there are multiple mechanisms of action by which endothelial cells stimulate $\beta$-cells (Beattie et al. 1996, Lammert et al. 2003, Brissova et al. 2006, Nikolova et al. 2006). One of these pathways implicated in IUGR is the hepatocyte growth factor (HGF) pathway, as pancreatic islet endothelial cells isolated from PI-IUGR fetuses produced less HGF compared to islet endothelial cells isolated from control fetal sheep (Rozance et al. 2015). HGF increases the insulin content of islets isolated from both PI-IUGR and control fetal sheep (Rozance et al. 2015, Brown et al. 2016). In adult islets, HGF also increases VEGFA secretion (Johansson et al. 2006). Finally, a complete mixture of amino acids, leucine individually, and VEGFA can all increase endothelial cell expression and/or production of HGF (Johansson et al. 2006, Brown et al. 2016). Importantly, when PI-IUGR fetuses were infused chronically with a complete mixture of amino acids enriched in the BCAAs, not only did islet size increase, but islet vascularity increased in proportion to the increase in islet size (Brown et al. 2016). Similar results occurred in the LP fetal rat, where gestational taurine supplementation prevented the decrease in fetal islet vascularity and VEGFA expression, and the increase in islet cell apoptosis (Abuzgaia et al. 2015). These were associated with higher $\beta$-cell mass in taurine supplemented LP fetal rats compared to non-supplemented LP fetal rats although insulin secretion was not enhanced (Boujendar et al. 2002, 2003). Together these findings suggest an impaired paracrine signaling loop between pancreatic endothelial and $\beta$-cells in cases of IUGR which may, in fact, be nutrient sensitive (reviewed in Rozance \& Hay 2016).

\section{Glucagon like peptide and inflammatory responses}

Glucagon like peptide-1 and its receptor agonist Exendin-4 $(\mathrm{Ex}-4)$ increase $\beta$-cell mass and enhance insulin secretion in UAL rats (Xu et al. 1999, Stoffers 2004, De León et al. 2006). A more subtle increase in insulin secretion occurred in Ex-4 treated UC-PI neonatal sheep (Liu et al. 2015), which may be due to the relative maturity of the neonatal sheep pancreas compared to the rat. In addition to preventing the deleterious effects of placental insufficiency on pancreatic islet dysfunction and the later development of diabetes, neonatal Ex-4 attenuated the decrease in pancreatic vascularity and islet VEGFA in UAL rats (Ham et al. 2009). The effect of Ex-4 occurs, in part, by reversing histone deacetylation and DNA methylation in the proximal promoter of Pdx1 in IUGR islets (Pinney et al. 2011). UAL rat fetuses are characterized by pancreatic islet lymphocyte and macrophage invasion with an associated transient inflammatory response which precedes the decrease in $\beta$-cell mass, GSIS, and islet vascularity. The local fetal islet immune and inflammatory response was inhibited with administration of a neutralizing interleukin-4 (IL-4) antibody during the neonatal period. The neutralizing IL-4 antibody also restored islet vascularity and $\beta$-cell function into adulthood, mechanistically linking inflammation with progressive islet failure in this model of IUGR. These results further underscore the importance of blood vessel and endothelial cell interactions with the $\beta$-cell in the pathogenesis of impaired islet development and function following placental insufficiency.

\section{Summary}

Further studies are needed to better characterize impaired islet and $\beta$-cell development and function throughout the lifespan of IUGR humans. In the meantime, results from animal models have provided substantial insights in the etiology of $\beta$-cell dysfunction in IUGR. Considerable evidence from the interventional studies discussed in this review indicates islet vascularity is an important regulator of $\beta$-cell development and function and that signaling between the endothelial cell and $\beta$-cell is likely to be involved in the pathogenesis of impaired islet function following placental insufficiency. Studies in both rat and sheep models have shown depressed islet vascularity and

Published by Bioscientifica Ltd. 
VEGFA in the IUGR fetal islets, which are improved by a number of interventions, including neutralizing IL-4 antibodies, Ex-4, and amino acids (Lammert et al. 2003, Ham et al. 2009, Liu et al. 2015, Rozance et al. 2015, Brown et al. 2016). Reduced vascularity in the IUGR islets may result in either reduced nutrient transfer to the $\beta$-cell or attenuate its ability to release insulin (Brissova et al. 2006, Richards et al. 2010). Additionally, the timing and duration of nutritional insults are critical in determining the severity of impaired islet function in IUGR. Although decreased $\beta$-cell mass, hypoinsulinemia, and lower insulin secretion are observed by $70 \%$ of gestation in IUGR fetal sheep, the magnitude of the decrement in these features of IUGR sheep becomes more pronounced as gestation progresses (Limesand et al. 2005, 2006, 2013). Likewise, earlier restriction in UAL fetal rats (E17 vs E18) results in a greater reduction of $\beta$-cell mass at one day of age (De Prins \& Van Assche 1982, Simmons et al. 2001). Similarly, the negative impact of nutrient restriction is enhanced when these restrictions are continued through lactation (Garofano et al. 1999, Dumortier et al. 2007).

\section{Future directions}

Recently, emergent omic technologies have been adopted for measurement of various molecules in SGA infants and animal models of IUGR. They provide a new opportunity for understanding the links between placental insufficiency and the later development of T2DM (Atzori et al. 2009, Dessì et al. 2013). Metabolic profiles of SGA children experiencing delayed 'catch up' growth suggest reduced insulin and IGF-I phospho-kinase mediated signaling (PI3K, AKT, and ERK). This likely reflects changes in cellular metabolism associated with insulin sensitivity and growth failure observed in these children (Murray et al. 2016). Differences in the metabolic profiles of IUGR or SGA neonates support the concept that defects in glucose and amino acid metabolism, insulin signaling, and angiogenesis contribute to the etiology of IUGR (Dessì et al. 2012, Conde-Agudelo et al. 2013). Another emergent technology, noninvasive, in vivo $\beta$-cell imaging, is being developed for clinical and investigational applications (Souza et al. 2006). Fluorescence imaging combined with several microscopy techniques have been successfully utilized to verify responsiveness to glucose and vascular networking in islet transplants or excised pancreases (Nyman et al. 2008, Speier et al. 2008). Adaptations of clinical imaging techniques including MRI, PET, and SPECT have been used to distinguish the exocrine and endocrine pancreas and increased resolution of these techniques may be enhanced by the continued evaluation of $\beta$-cell specific contrast agents and radioligands (Antkowiak et al. 2009, Moore 2009, Steyn et al. 2015, Willekens et al. 2015). Further development of in vivo imaging techniques will allow for detailed investigation of complex cellular processes regulating $\beta$-cell proliferation, vascularization, and insulin secretion in pathophysiological conditions. These studies will provide valuable insights to the etiology of impaired $\beta$-cell function following IUGR and how the $\beta$-cell mass changes over the lifespan of these individuals.

Current reviews suggest maternal or neonatal nutrient supplementation has little impact in mitigating IUGR in humans (Hay 2008, Brown et al. 2011, Devaskar \& Chu 2016). Furthermore, most nutritional interventions are associated with increased adiposity and not increased linear growth. More promising are interventions which increase uterine blood flow (David et al. 2008, Satterfield et al. 2010, von Dadelszen et al. 2011, Mehta et al. 2014, Carr et al. 2016, Oyston et al. 2016). Despite this progress, animal studies are required to evaluate the effect of these interventions on the fetal pathophysiological processes described in this review and to refine further the therapies to specific complications of placental insufficiency. Given the length of time between birth and the development of T2DM in humans, animal models are also required to test the impact of perinatal interventions on the development of insulin resistance, $\beta$-cell failure and T2DM throughout the lifespan. In addition to improving the healthy growth of the fetus and prolonging pregnancy, interventions that restore normal islet development and $\beta$-cell function are needed to diminish the onset of obesity, insulin resistance, and T2DM as these individuals reach adulthood.

\section{Declaration of interest}

The authors declare that there is no conflict of interest that could be perceived as prejudicing the impartiality of this review.

\section{Funding}

This work was supported by NIH Grants R01DK088139 (P J R, P I), T32007186 (B H B, Fellow), and R01DK084842 (S W L, P I). This content is solely the responsibility of the authors and does not represent the views of NICHD or NIDDK.

\section{References}

Abuzgaia AM, Hardy DB \& Arany E 2015 Regulation of postnatal pancreatic Pdx1 and downstream target genes after gestational

Published by Bioscientifica Ltd. 
exposure to protein restriction in rats. Reproduction 149 293-303. (doi:10.1530/REP-14-0245)

Aldoretta PW \& Hay WW 1999 Effect of glucose supply on ovine uteroplacental glucose metabolism. American Journal of Physiology: Regulatory, Integrative and Comparative Physiology 277 R947-R958.

Andersson LE, Valtat B, Bagge A, Sharoyko VV, Nicholls DG, Ravassard P, Scharfmann R, Spégel P \& Mulder H 2015 Characterization of stimulus-secretion coupling in the human pancreatic endoc- $\beta \mathrm{h} 1$ beta cell line. PLOS ONE 10 e0120879. (doi:10.1371/journal.pone.0120879)

Andrews SE, Brown LD, Thorn SR, Limesand SW, Davis M, Hay WW \& Rozance PJ 2015 Increased adrenergic signaling is responsible for decreased glucose-stimulated insulin secretion in the chronically hyperinsulinemic ovine fetus. Endocrinology 156 367-376. (doi:10.1210/en.2014-1393)

Antkowiak PF, Tersey SA, Carter JD, Vandsburger MH, Nadler JL, Epstein FH \& Mirmira RG 2009 Noninvasive assessment of pancreatic $\beta$-cell function in vivo with manganese-enhanced magnetic resonance imaging. American Journal of Physiology: Endocrinology and Metabolism 296 E573-E578. (doi:10.1152/ajpendo.90336.2008)

Arya VB, Flanagan SE, Kumaran A, Shield JP, Ellard S, Hussain K \& Kapoor RR 2013 Clinical and molecular characterisation of hyperinsulinaemic hypoglycaemia in infants born small-for-gestational age. Archives of Disease in Childhood. Fetal and Neonatal Edition 98 F356-F358. (doi:10.1136/archdischild-2012-302880)

Atzori L, Antonucci R, Barberini L, Griffin JL \& Fanos V 2009 Metabolomics: a new tool for the neonatologist. Journal of Maternal-Fetal and Neonatal Medicine 22 50-53. (doi:10.1080/14767050903181500)

Barker DJP, Hales CN, Fall CHD, Osmond C, Phipps K \& Clark PMS 1993 Type 2 (non-insulin-dependent) diabetes mellitus, hypertension and hyperlipidaemia (syndrome $\mathrm{X}$ ): relation to reduced fetal growth. Diabetologia 36 62-67. (doi:10.1007/BF00399095)

Bazaes RA, Salazar TE, Pittaluga E, Peña V, Alegría A, Íñiguez G, Ong KK, Dunger DB \& Mericq MV 2003 Glucose and lipid metabolism in small for gestational age infants at 48 hours of age. Pediatrics 111 804-809. (doi:10.1542/peds.111.4.804)

Beattie GM, Rubin JS, Mally MI, Otonkoski T \& Hayek A 1996 Regulation of proliferation and differentiation of human fetal pancreatic islet cells by extracellular matrix, hepatocyte growth factor, and cell-cell contact. Diabetes 45 1223-1228. (doi:10.2337/diab.45.9.1223)

Bell AW, Wilkening RB \& Meschia G 1987 Some aspects of placental function in chronically heat-stressed ewes. Journal of Developmental Physiology 9 17-29.

Benjamin JS, Culpepper CB, Brown LD, Wesolowski SR, Jonker SS, Davis MA, Limesand SW, Wilkening RB, Hay WW \& Rozance PJ 2017 Chronic anemic hypoxemia attenuates glucose-stimulated insulin aecretion in fetal sheep. American Journal of Physiology: Regulatory, Integrative and Comparative Physiology 312 R492-R500.

Béringue F, Blondeau B, Castellotti MC, Bréant B, Czernichow P \& Polak M 2002 Endocrine pancreas development in growth-retarded human fetuses. Diabetes 51 385-391.

Boujendar S, Reusens B, Merezak S, Ahn M-T, Arany E, Hill D \& Remacle C 2002 Taurine supplementation to a low protein diet during foetal and early postnatal life restores a normal proliferation and apoptosis of rat pancreatic islets. Diabetologia 45 856-866. (doi:10.1007/s00125-002-0833-6)

Boujendar S, Arany E, Hill D, Remacle C \& Reusens B 2003 Taurine supplementation of a low protein diet fed to rat dams normalizes the vascularization of the fetal endocrine pancreas. Journal of Nutrition 133 2820-2825.

Brissova M, Shostak A, Shiota M, Wiebe PO, Poffenberger G, Kantz J, Chen Z, Carr C, Jerome WG, Chen J, et al. 2006 Pancreatic islet production of vascular endothelial growth factor-A is essential for islet vascularization, revascularization, and function. Diabetes $\mathbf{5 5}$ 2974-2985. (doi:10.2337/db06-0690)

Brown LD, Rozance PJ, Barry JS, Friedman JE \& Hay WW 2009 Insulin is required for amino acid stimulation of dual pathways for translational control in skeletal muscle in the late-gestation ovine fetus. American Journal of Physiology: Endocrinology and Metabolism 296 E56-E63. (doi:10.1152/ajpendo.90310.2008)

Brown LD, Green AS, Limesand SW \& Rozance PJ 2011 Maternal amino acid supplementation for intrauterine growth restriction. Frontiers in Bioscience 3 428-444.

Brown LD, Rozance PJ, Thorn SR, Friedman JE \& Hay WW 2012 Acute supplementation of amino acids increases net protein accretion in IUGR fetal sheep. American Journal of Physiology: Endocrinology and Metabolism 303 E352-E364. (doi:10.1152/ajpendo.00059.2012)

Brown LD, Davis M, Wai S, Wesolowski SR, Hay WW Jr, Limesand SW \& Rozance PJ 2016 Chronically increased amino acids improve insulin secretion, pancreatic vascularity, and islet size in growth-restricted fetal sheep. Endocrinology 157 3788-3799.

Camacho LE, Chen X, Hay WW \& Limesand SW 2017 Enhanced insulin secretion and insulin sensitivity in young lambs with placental insufficiency-induced intrauterine growth restriction. American Journal of Physiology: Regulatory, Integrative and Comparative Physiology 313 R101-R108.

Carr DJ, Wallace JM, Aitken RP, Milne JS, Martin JF, Zachary IC, Peebles DM \& David AL 2016 Peri- and postnatal effects of prenatal adenoviral VEGF gene therapy in growth-restricted sheep. Biology of Reproduction 94142.

Cetin I 2003 Placental transport of amino acids in normal and growthrestricted pregnancies. European Journal of Obstetrics and Gynecology and Reproductive Biology 110 (Supplement) S50-S54. (doi:10.1016/ S0301-2115(03)00172-6)

Cetin I, Corbetta C, Sereni LP, Marconi AM, Bozzetti P, Pardi G \& Battaglia FC 1990 Umbilical amino acid concentrations in normal and growth-retarded fetuses sampled in utero by cordocentesis. American Journal of Obstetrics and Gynecology 162 253-261. (doi:10.1016/00029378(90)90860-A)

Chen X, Green AS, Macko AR, Yates DT, Kelly AC \& Limesand SW 2014 Enhanced insulin secretion responsiveness and islet adrenergic desensitization after chronic norepinephrine suppression is discontinued in fetal sheep. American Journal of Physiology: Endocrinology and Metabolism 306 E58-E64. (doi:10.1152/ ajpendo.00517.2013)

Chen X, Kelly AC, Yates DT, Macko AR, Lynch RM \& Limesand SW 2017 Islet adaptations in fetal sheep persist following chronic exposure to high norepinephrine. Journal of Endocrinology 232 285-295. (doi:10.1530/JOE-16-0445)

Cline GW, Pongratz RL, Zhao X \& Papas KK 2011 Rates of insulin secretion in INS-1 cells are enhanced by coupling to anaplerosis and Kreb's cycle flux independent of ATP synthesis. Biochemical and Biophysical Research Communications 415 30-35. (doi:10.1016/j. bbrc.2011.09.153)

Collins JE \& Leonard JV 1984 Hyperinsulinism in asphyxiated and small-for-dates infants with hypoglycaemia. Lancet 324 311-313. (doi:10.1016/S0140-6736(84)92685-0)

Conde-Agudelo A, Papageorghiou AT, Kennedy SH \& Villar J 2013 Novel biomarkers for predicting intrauterine growth restriction: a systematic review and meta-analysis. BJOG 120 681-694. (doi:10.1111/14710528.12172)

Conrad E, Stein R \& Hunter CS 2014 Revealing transcription factors during human pancreatic $\beta$ cell development. Trends in Endocrinology and Metabolism 25 407-414. (doi:10.1016/j.tem.2014.03.013)

Cook JT, Levy JC, Page RC, Shaw JA, Hattersley AT \& Turner RC 1993 Association of low birth weight with beta cell function in the adult first degree relatives of non-insulin dependent diabetic subjects. BMJ 306 302-306. (doi:10.1136/bmj.306.6873.302)

Crovetto F, Triunfo S, Crispi F, Rodriguez-Sureda V, Dominguez C, Figueras F \& Gratacos E 2016 Differential performance of first trimester screening in predicting small for gestational age neonates or fetal growth restriction. Ultrasound in Obstetrics and Gynecology 49 349-356. (doi:10.1002/uog.15919) 
Crowther NJ, Trusler J, Cameron N, Toman M \& Gray PI 2000 Relation between weight gain and beta-cell secretory activity and nonesterified fatty acid production in 7-year-old African children: results from the Birth to Ten study. Diabetologia 43 978-985. (doi:10.1007/ s001250051479)

David AL, Torondel B, Zachary I, Wigley V, Nader KA, Mehta V, Buckley SMK, Cook T, Boyd M, Rodeck CH, et al. 2008 Local delivery of VEGF adenovirus to the uterine artery increases vasorelaxation and uterine blood flow in the pregnant sheep. Gene Therapy 15 1344-1350. (doi:10.1038/gt.2008.102)

De Blasio MJ, Gatford KL, McMillen IC, Robinson JS \& Owens JA 2007 Placental restriction of fetal growth increases insulin action, growth, and adiposity in the young lamb. Endocrinology 148 1350-1358. (doi:10.1210/en.2006-0653)

De León DD, Crutchlow MF, Ham J-YN \& Stoffers DA 2006 Role of glucagon-like peptide- 1 in the pathogenesis and treatment of diabetes mellitus. International Journal of Biochemistry and Cell Biology $\mathbf{3 8}$ 845-859. (doi:10.1016/j.biocel.2005.07.011)

De Prins F \& Van Assche F 1982 Intrauterine growth retardation and development of endocrine pancreas in the experimental rat. Biology of the Neonate 41 16-21. (doi:10.1159/000241511)

de Vrijer B, Regnault TRH, Wilkening RB, Meschia G \& Battaglia FC 2004 Placental uptake and transport of ACP, a neutral nonmetabolizable amino acid, in an ovine model of fetal growth restriction. American Journal of Physiology: Endocrinology and Metabolism 287 E1114-E1124. (doi:10.1152/ajpendo.00259.2004)

Delghingaro-Augusto V, Madad L, Chandra A, Simeonovic CJ, Dahlstrom JE \& Nolan CJ 2014 Islet inflammation, hemosiderosis, and fibrosis in intrauterine growth-restricted and high fat-fed Sprague-Dawley rats. American Journal of Pathology 184 1446-1457. (doi:10.1016/j. ajpath.2014.01.024)

Dessì A, Ottonello G \& Fanos V 2012 Physiopathology of intrauterine growth retardation: from classic data to metabolomics. Journal of Maternal-Fetal and Neonatal Medicine 25 13-18.

Dessì A, Puddu M, Ottonello G \& Fanos V 2013 Metabolomics and fetalneonatal nutrition: between 'not enough' and 'too much'. Molecules 18 11724-11732.

Devaskar SU \& Chu A 2016 Intrauterine growth restriction: hungry for an answer. Physiology 31 131-146.

DiGiacomo JE \& Hay WW 1990 Fetal glucose metabolism and oxygen consumption during sustained hypoglycemia. Metabolism 39 193-202. (doi:10.1016/0026-0495(90)90075-N)

Dionne KE, Colton CK \& Lyarmush M 1993 Effect of hypoxia on insulin secretion by isolated rat and canine islets of Langerhans. Diabetes $\mathbf{4 2}$ 12-21. (doi:10.2337/diab.42.1.12)

Doliba NM, Wehrli SL, Vatamaniuk MZ, Qin W, Buettger CW, Collins HW \& Matschinsky FM 2007 Metabolic and ionic coupling factors in amino acid-stimulated insulin release in pancreatic $\beta$-HC9 cells. American Journal of Physiology: Endocrinology and Metabolism 292 E1507-E1519. (doi:10.1152/ajpendo.00282.2006)

Dumortier O, Blondeau B, Duvillie B, Reusens B, Bréant B \& Remacle C 2007 Different mechanisms operating during different critical timewindows reduce rat fetal beta cell mass due to a maternal low-protein or low-energy diet. Diabetologia 50 2495-2503. (doi:10.1007/s00125007-0811-0)

Economides D, Proudler A \& Nicolaides K 1989 Plasma insulin in appropriate-and small-for-gestational-age fetuses. American Journal of Obstetrics and Gynecology 160 1091-1094. (doi:10.1016/00029378(89)90167-1)

Erion KA, Berdan CA, Burritt NE, Corkey BE \& Deeney JT 2015 Chronic exposure to excess nutrients left-shifts the concentration dependence of glucose-stimulated insulin secretion in pancreatic $\beta$-cells. Journal of Biological Chemistry 290 16191-16201. (doi:10.1074/jbc. M114.620351)

Fabricius-Bjerre S, Jensen RB, Færch K, Larsen T, Mølgaard C, Michaelsen KF, Vaag A \& Greisen G 2011 Impact of birth weight and early infant

http://joe.endocrinology-journals.org

DOI: 10.1530/JOE-17-0076
๑ 2017 Society for Endocrinology Printed in Great Britain weight gain on insulin resistance and associated cardiovascular risk factors in adolescence. PLoS ONE 6 e20595. (doi:10.1371/journal. pone.0020595)

Fernandez-Twinn DS, Wayman A, Ekizoglou S, Martin MS, Hales CN \& Ozanne SE 2005 Maternal protein restriction leads to hyperinsulinemia and reduced insulin-signaling protein expression in 21-mo-old female rat offspring. American Journal of Physiology: Regulatory, Integrative and Comparative Physiology 288 R368-R373. (doi:10.1152/ajpregu.00206.2004)

Forsén T, Eriksson J, Tuomilehto J, Reunanen A, Osmond C \& Barker D 2000 SIze at birth, growth in childhood, and the risk for type 2 diabetes. Annals of Internal Medicine 133 176-182.

Fowden AL, Hughes P \& Comline RS 1989 The effects of insulin on the growth rate of the sheep fetus during late gestation. Quarterly Journal of Experimental Physiology 74 703-714. (doi:10.1113/expphysiol.1989. sp003322)

Fridlyand LE \& Philipson LH 2016 Pancreatic beta cell G-protein coupled receptors and second messenger interactions: a systems biology computational analysis. PLOS ONE 11 e0152869. (doi:10.1371/ journal.pone.0152869)

Gadhia MM, Maliszewski AM, O'Meara MC, Thorn SR, Lavezzi JR, Limesand SW, Hay Jr WW, Brown LD \& Rozance PJ 2013 Increased amino acid supply potentiates glucose-stimulated insulin secretion but does not increase $\beta$-cell mass in fetal sheep. American Journal of Physiology: Endocrinology and Metabolism 304 E352-E362. (doi:10.1152/ajpendo.00377.2012)

Galan HL, Hussey MJ, Barbera A, Ferrazzi E, Chung M, Hobbins JC \& Battaglia FC 1999 Relationship of fetal growth to duration of heat stress in an ovine model of placental insufficiency. American Journal of Obstetrics and Gynecology 180 1278-1282. (doi:10.1016/S00029378(99)70629-0)

Galan HL, Marconi AM, Paolini CL, Cheung A \& Battaglia FC 2009 The transplacental transport of essential amino acids in uncomplicated human pregnancies. American Journal of Obstetrics and Gynecology 200 91.e91-91.e97.

Gao Z, Young RA, Li G, Najafi H, Buettger C, Sukumvanich SS, Wong RK, Wolf BA \& Matschinsky FM 2003 Distinguishing features of leucine and $\alpha$-ketoisocaproate sensing in pancreatic $\beta$-cells. Endocrinology 144 1949-1957.

Garofano A, Czernichow P \& Breant B 1997 In utero undernutrition impairs rat beta-cell development. Diabetologia 40 1231-1234. (doi:10.1007/s001250050812)

Garofano A, Czernichow P \& Breant B 1998 Beta-cell mass and proliferation following late fetal and early postnatal malnutrition in the rat. Diabetologia 41 1114-1120. (doi:10.1007/ s001250051038)

Garofano A, Czernichow P \& Breant B 1999 Effect of ageing on beta-cell mass and function in rats malnourished during the perinatal period. Diabetologia 42 711-718. (doi:10.1007/s001250051219)

Gatford KL, Mohammad SNB, Harland ML, De Blasio MJ, Fowden AL, Robinson JS \& Owens JA 2008 Impaired $\beta$-cell function and inadequate compensatory increases in $\beta$-cell mass after intrauterine growth restriction in sheep. Endocrinology 149 5118-5127. (doi:10.1210/en.2008-0233)

German MS 1993 Glucose sensing in pancreatic islet beta cells: the key role of glucokinase and the glycolytic intermediates. PNAS 90 1781-1785. (doi:10.1073/pnas.90.5.1781)

Gleason CE, Lu D, Witters LA, Newgard CB \& Birnbaum MJ 2007 The role of AMPK and mTOR in nutrient sensing in pancreatic $\beta$-cells. Journal of Biological Chemistry 282 10341-10351. (doi:10.1074/jbc. M610631200)

Göhring I, Sharoyko VV, Malmgren S, Andersson LE, Spégel P, Nicholls DG \& Mulder H 2014 Chronic high glucose and pyruvate levels differentially affect mitochondrial bioenergetics and fuel-stimulated insulin secretion from clonal INS-1 832/13 cells. Journal of Biological Chemistry 289 3786-3798. 
Green AS, Rozance PJ \& Limesand SW 2010 Consequences of a compromised intrauterine environment on islet function. Journal of Endocrinology 205 211-224. (doi:10.1677/JOE-09-0399)

Greenough A, Nicolaides KH \& Lagercrantz H 1990 Human fetal sympathoadrenal responsiveness. Early Human Development 23 9-13. (doi:10.1016/0378-3782(90)90124-2)

Hales CN \& Barker DJ 2001 The thrifty phenotype hypothesis. British Medical Bulletin 60 5-20. (doi:10.1093/bmb/60.1.5)

Ham JN, Crutchlow MF, Desai BM, Simmons RA \& Stoffers DA 2009 Exendin-4 normalizes islet vascularity in intrauterine growth restricted rats: potential role of VEGF. Pediatric Research 66 42-46. (doi:10.1203/PDR.0b013e3181a282a5)

Hay WW 2008 Strategies for feeding the preterm infant. Neonatology 94 245-254. (doi:10.1159/000151643)

Hay WW, Meznarich HK, Digiacomo JE, Hirst K \& Zerbe G 1988 Effects of insulin and glucose concentrations on glucose utilization in fetal sheep. Pediatric Research 23 381-387. (doi:10.1203/00006450198804000-00008)

Hendrix N \& Berghella V 2008 Non-placental causes of intrauterine growth restriction. Seminars in Perinatology 32 161-165. (doi:10.1053/j.semperi.2008.02.004)

Henquin JC 2000 Triggering and amplifying pathways of regulation of insulin secretion by glucose. Diabetes 49 1751-1760. (doi:10.2337/ diabetes.49.11.1751)

Huang M \& Joseph JW 2012 Metabolomic analysis of pancreatic $\beta$-cell insulin release in response to glucose. Islets 4 210-222. (doi:10.4161/ isl.20141)

Huypens P, Ling Z, Pipeleers D \& Schuit F 2000 Glucagon receptors on human islet cells contribute to glucose competence of insulin release. Diabetologia 43 1012-1019. (doi:10.1007/s001250051484)

Ikeda N, Shoji H, Suganuma H, Ohkawa N, Kantake M, Murano Y, Sakuraya K \& Shimizu T 2016 Effect of insulin-like growth factor-I during the early postnatal period in intrauterine growth-restricted rats. Pediatrics International 58 353-358. (doi:10.1111/ped.12855)

Jansson T, Scholtbach V \& Powell TL 1998 Placental transport of leucine and lysine is reduced in intrauterine growth restriction. Pediatric Research 44 532-537. (doi:10.1203/00006450-199810000-00011)

Jennings RE, Berry AA, Strutt JP, Gerrard DT \& Hanley NA 2015 Human pancreas development. Development 142 3126-3137. (doi:10.1242/ dev.120063)

Jensen CB, Storgaard H, Dela F, Holst JJ, Madsbad S \& Vaag AA 2002 Early differential defects of insulin secretion and action in 19-year-old Caucasian men who had low birth weight. Diabetes 51 1271-1280. (doi:10.2337/diabetes.51.4.1271)

Johansson M, Mattsson G, Andersson A, Jansson L \& Carlsson P-O 2006 Islet endothelial cells and pancreatic $\beta$-cell proliferation: studies in vitro and during pregnancy in adult rats. Endocrinology $\mathbf{1 4 7}$ 2315-2324. (doi:10.1210/en.2005-0997)

Kajantie E, Strang-Karlsson S, Hovi P, Wehkalampi K, Lahti J, Kaseva N, Järvenpää A-L, Räikkönen K, Eriksson JG \& Andersson S 2015 Insulin sensitivity and secretory response in adults born preterm: the Helsinki Study of very low birth weight adults. Journal of Clinical Endocrinology and Metabolism 100 244-250. (doi:10.1210/jc.2014-3184)

Kasuga M 2006 Insulin resistance and pancreatic $\beta$ cell failure. Journal of Clinical Investigation 116 1756-1760. (doi:10.1172/JCI29189)

Kelly AC, Bidwell CA, McCarthy FM, Taska DJ, Andersen MJ, Camacho LE \& Limesand SW 2017 RNA sequencing exposes novel adaptive and immune responses to intrauterine growth restriction in fetal sheep islets. Endocrinology 158 743-755. (doi:10.1210/en.2016-1901)

Lammert E, Gu G, McLaughlin M, Brown D, Brekken R, Murtaugh LC, Gerber H-P, Ferrara N \& Melton DA 2003 Role of VEGF-A in vascularization of pancreatic islets. Current Biology 13 1070-1074. (doi:10.1016/S0960-9822(03)00378-6)

Lavezzi JR, Thorn SR, O’Meara MC, LoTurco D, Brown LD, Hay WW \& Rozance PJ 2013 Increased fetal insulin concentrations for one week fail to improve insulin secretion or $\beta$-cell mass in fetal sheep with http://joe.endocrinology-journals.org

DOI: $10.1530 / \mathrm{JOE}-17-0076$
(C) 2017 Society for Endocrinology Printed in Great Britain chronically reduced glucose supply. American Journal of Physiology: Regulatory, Integrative and Comparative Physiology 304 R50-R58. (doi:10.1152/ajpregu.00413.2012)

Leos RA, Anderson MJ, Chen X, Pugmire J, Anderson KA \& Limesand SW 2010 Chronic exposure to elevated norepinephrine suppresses insulin secretion in fetal sheep with placental insufficiency and intrauterine growth restriction. American Journal of Physiology: Endocrinology and Metabolism 298 E770-E778. (doi:10.1152/ajpendo.00494.2009)

Limesand SW \& Hay WW 2003 Adaptation of ovine fetal pancreatic insulin secretion to chronic hypoglycaemia and euglycaemic correction. Journal of Physiology 547 95-105. (doi:10.1113/ jphysiol.2002.026831)

Limesand SW, Jensen J, Hutton JC \& Hay WW 2005 Diminished $\beta$-cell replication contributes to reduced $\beta$-cell mass in fetal sheep with intrauterine growth restriction. American Journal of Physiology: Regulatory, Integrative and Comparative Physiology 288 R1297-R1305. (doi:10.1152/ajpregu.00494.2004)

Limesand SW, Rozance PJ, Zerbe GO, Hutton JC \& Hay WW Jr 2006 Attenuated insulin release and storage in fetal sheep pancreatic islets with intrauterine growth restriction. Endocrinology 147 1488-1497.

Limesand SW, Rozance PJ, Macko AR, Anderson MJ, Kelly AC \& Hay WW 2013 Reductions in insulin concentrations and $\beta$-cell mass precede growth restriction in sheep fetuses with placental insufficiency. American Journal of Physiology: Endocrinology and Metabolism 304 E516-E523. (doi:10.1152/ajpendo.00435.2012)

Liu H, Schultz CG, De Blasio MJ, Peura AM, Heinemann GK, Harryanto H, Hunter DS, Wooldridge AL, Kind KL, Giles LC, et al. 2015 Effect of placental restriction and neonatal exendin-4 treatment on postnatal growth, adult body composition, and in vivo glucose metabolism in the sheep. American Journal of Physiology: Endocrinology and Metabolism 309 E589-E600. (doi:10.1152/ajpendo.00487.2014)

MacDonald MJ, McKenzie DI, Kaysen JH, Walker TM, Moran SM, Fahien LA \& Towle HC 1991 Glucose regulates leucine-induced insulin release and the expression of the branched chain ketoacid dehydrogenase E1 alpha subunit gene in pancreatic islets. Journal of Biological Chemistry 266 1335-1340.

Macko AR, Yates DT, Chen X, Green AS, Kelly AC, Brown LD \& Limesand SW 2013 Elevated plasma norepinephrine inhibits insulin secretion, but adrenergic blockade reveals enhanced $\beta$-cell responsiveness in an ovine model of placental insufficiency at 0.7 of gestation. Journal of Developmental Origins of Health and Disease 4 402-410. (doi:10.1017/ S2040174413000093)

Macko AR, Yates DT, Chen X, Shelton LA, Kelly AC, Davis MA, Camacho LE, Anderson MJ \& Limesand SW 2016 Adrenal demedullation and oxygen supplementation independently increase glucose-stimulated insulin concentrations in fetal sheep with intrauterine growth restriction. Endocrinology 157 2104-2115. (doi:10.1210/en.2015-1850)

Malaisse W, Sener A, Herchuelz A \& Hutton J 1979 Insulin release: the fuel hypothesis. Metabolism 28 373-386. (doi:10.1016/00260495(79)90111-2)

Maliszewski AM, Gadhia MM, O'Meara MC, Thorn SR, Rozance PJ \& Brown LD 2012 Prolonged infusion of amino acids increases leucine oxidation in fetal sheep. American Journal of Physiology: Endocrinology and Metabolism 302 E1483-E1492. (doi:10.1152/ajpendo.00026.2012)

Marconi AM, Paolini CL, Stramare L, Cetin I, Fennessey PV, Pardi G \& Battaglia FC 1999 Steady state maternal-fetal leucine enrichments in normal and intrauterine growth-restricted pregnancies. Pediatric Research 46 114-119. (doi:10.1203/00006450-199907000-00019)

Marconi AM, Paolini CL, Zerbe G \& Battaglia FC 2006 Lactacidemia in intrauterine growth restricted (IUGR) pregnancies: relationship to clinical severity, oxygenation and placental weight. Pediatric Research 59 570-574. (doi:10.1203/01.pdr.0000205477.70391.3e)

Mathai S, Cutfield WS, Derraik JGB, Dalziel SR, Harding JE, Robinson E, Biggs J, Jefferies C \& Hofman PL 2012 Insulin sensitivity and $\beta$-cell function in adults born preterm and their children. Diabetes $\mathbf{6 1}$ 2479-2483. (doi:10.2337/db11-1672) 
Mayhew TM, Ohadike C, Baker PN, Crocker IP, Mitchell C \& Ong SS 2003 Stereological investigation of placental morphology in pregnancies complicated by pre-eclampsia with and without intrauterine growth restriction. Placenta 24 219-226. (doi:10.1053/plac.2002.0900)

Mehta V, Abi-Nader KN, Shangaris P, Shaw SW, Filippi E, Benjamin E, Boyd M, Peebles DM, Martin J, Zachary I, et al. 2014 Local overexpression of VEGF-D ${ }^{\Delta N \Delta C}$ in the uterine arteries of pregnant sheep results in long-term changes in uterine artery contractility and angiogenesis. PLOS ONE 9 e100021. (doi:10.1371/journal. pone.0100021)

Mellor DJ, Mitchell B \& Matheson IC 1977 Reductions in lamb weight caused by pre-mating carunclectomy and mid-pregnancy placental ablation. Journal of Comparative Pathology 87 629-633. (doi:10.1016/0021-9975(77)90070-6)

Mericq V, Ong KK, Bazaes R, Pena V, Avila A, Salazar T, Soto N, Iniguez G \& Dunger DB 2005 Longitudinal changes in insulin sensitivity and secretion from birth to age three years in small-and appropriate-forgestational-age children. Diabetologia 48 2609-2614. (doi:10.1007/ s00125-005-0036-z)

Milner RDG 1969 Stimulation of insulin secretion in vitro by essential amino acids. Lancet 293 1075-1076. (doi:10.1016/S01406736(69)91709-7)

Milovanovic I, Njuieyon F, Deghmoun S, Chevenne D, Levy-Marchal C $\&$ Beltrand J 2014 SGA children with moderate catch-up growth are showing the impaired insulin secretion at the age of 4. PLOS ONE 9 e100337. (doi:10.1371/journal.pone.0100337)

Molina RD, Carver TD \& Hay WW 1993 Ontogeny of insulin effect in fetal sheep. Pediatric Research 34 654-660. (doi:10.1203/00006450199311000-00018)

Moore A 2009 Advances in beta-cell imaging. European Journal of Radiology 70 254-257. (doi:10.1016/j.ejrad.2009.01.044)

Murray PG, Butcher I, Dunn WB, Stevens A, Perchard R, Hanson D, Whatmore A, Westwood M \& Clayton PE 2016 Metabolites involved in glycolysis and amino acid metabolism are altered in short children born small for gestational age. Pediatric Research 80 299-305.

Newgard Christopher B 2012 Interplay between lipids and branchedchain amino acids in development of insulin resistance. Cell Metabolism 15 606-614. (doi:10.1016/j.cmet.2012.01.024)

Newsholme P, Brennan L \& Bender K 2006 Amino acid metabolism, $\beta$-cell function, and diabetes. Diabetes 55 S39-S47. (doi:10.2337/db06-S006)

Newsholme P, Cruzat V, Arfuso F \& Keane K 2014 Nutrient regulation of insulin secretion and action. Journal of Endocrinology 221 R105-R120. (doi:10.1530/JOE-13-0616)

Nicolini U, Hubinont C, Santolaya J, Fisk N \& Rodeck C 1990 Effects of fetal intravenous glucose challenge in normal and growth retarded fetuses. Hormone and Metabolic Research 22 426-430. (doi:10.105 5/s-2007-1004939)

Nikolova G, Jabs N, Konstantinova I, Domogatskaya A, Tryggvason K, Sorokin L, Fässler R, Gu G, Gerber H-P, Ferrara N, et al. 2006 The vascular basement membrane: a niche for insulin gene expression and $\beta$ cell proliferation. Developmental Cell 10 397-405. (doi:10.1016/j. devcel.2006.01.015)

Nyman LR, Wells KS, Head WS, McCaughey M, Ford E, Brissova M, Piston DW \& Powers AC 2008 Real-time, multidimensional in vivo imaging used to investigate blood flow in mouse pancreatic islets. Journal of Clinical Investigation 118 3790-3797. (doi:10.1172/JCI36209)

Ogata ES, Bussey ME \& Finley S 1986 Altered gas exchange, limited glucose and branched chain amino acids, and hypoinsulinism retard fetal growth in the rat. Metabolism 35 970-977. (doi:10.1016/00260495(86)90064-8)

Owens JA, Gatford KL, De Blasio MJ, Edwards LJ, McMillen IC \& Fowden AL 2007 Restriction of placental growth in sheep impairs insulin secretion but not sensitivity before birth. Journal of Physiology $\mathbf{5 8 4}$ 935-949. (doi:10.1113/jphysiol.2007.142141)

Oyston C, Stanley JL, Oliver MH, Bloomfield FH \& Baker PN 2016 Maternal administration of sildenafil citrate alters fetal and placental growth and fetal-placental vascular resistance in the growthrestricted ovine fetus. Hypertension 68 760-767. (doi:10.1161/ HYPERTENSIONAHA.116.07662)

Paolini CL, Marconi AM, Ronzoni S, Di Noio M, Fennessey PV, Pardi G \& Battaglia FC 2001 Placental transport of leucine, phenylalanine, glycine, and proline in intrauterine growth-restricted pregnancies. Journal of Clinical Endocrinology and Metabolism 86 5427-5432. (doi:10.1210/jcem.86.11.8036)

Patel MS, Srinivasan M, Strutt B, Mahmood S \& Hill DJ 2014 Featured article: beta cell specific pyruvate dehydrogenase alpha gene deletion results in a reduced islet number and $\beta$-cell mass postnatally. Experimental Biology and Medicine 239 975-985 (doi:10.1177/1535370214531895)

Petrik J, Reusens B, Arany E, Remacle C, Coelho C, Hoet JJ \& Hill DJ 1999 A low protein diet alters the balance of islet cell replication and apoptosis in the fetal and neonatal rat and is associated with a reduced pancreatic expression of insulin-like growth factor-II. Endocrinology 140 4861-4873. (doi:10.1210/endo.140.10.7042)

Pinney SE, Jaeckle Santos LJ, Han Y, Stoffers DA \& Simmons RA 2011 Exendin-4 increases histone acetylase activity and reverses epigenetic modifications that silence Pdx1 in the intrauterine growth retarded rat. Diabetologia 54 2606-2614. (doi:10.1007/s00125-011-2250-1)

Pipeleers DG, Schuit FC, In't Veld PA, Maes E, Hooghe-Peters EL, Van De Winkel M \& Gepts W 1985 Interplay of nutrients and hormones in the regulation of insulin release. Endocrinology 117 824-833. (doi:10.1210/endo-117-3-824)

Platz E \& Newman R 2008 Diagnosis of IUGR: traditional biometry. Seminars in Perinatology 32 140-147. (doi:10.1053/j. semperi.2008.02.002)

Regnault TRH, de Vrijer B \& Battaglia FC 2002a Transport and metabolism of amino acids in placenta. Endocrine 19 23-41. (doi:10.1385/ENDO:19:1:23)

Regnault TRH, Galan HL, Parker TA \& Anthony RV $2002 b$ Placental development in normal and compromised pregnancies - a review. Placenta 23 S119-S129. (doi:10.1053/plac.2002.0792)

Reinert RB, Brissova M, Shostak A, Pan FC, Poffenberger G, Cai Q, Hundemer GL, Kantz J, Thompson CS, Dai C, et al. 2013 Vascular endothelial growth factor-A and islet vascularization are necessary in developing, but not adult, pancreatic islets. Diabetes 62 4154-4164. (doi:10.2337/db13-0071)

Richards OC, Raines SM \& Attie AD 2010 The role of blood vessels, endothelial cells, and vascular pericytes in insulin secretion and peripheral insulin action. Endocrine Reviews 31 343-363. (doi:10.1210/ er.2009-0035)

Robinson JS, Kingston EJ, Jones CT \& Thorburn GD 1979 Studies on experimental growth retardation in sheep. The effect of removal of a endometrial caruncles on fetal size and metabolism. Journal of Developmental Physiology 1 379-398.

Rosengren AH, Jokubka R, Tojjar D, Granhall C, Hansson O, Li D-Q, Nagaraj V, Reinbothe TM, Tuncel J, Eliasson L, et al. 2010 Overexpression of alpha2A-adrenergic receptors contributes to type 2 diabetes. Science 327 217-220. (doi:10.1126/ science.1176827)

Rozance PJ \& Hay WW 2006 Hypoglycemia in newborn infants: features associated with adverse outcomes. Neonatology 90 74-86. (doi:10.1159/000091948)

Rozance PJ \& Hay WW 2016 Pancreatic islet hepatocyte growth factor and vascular endothelial growth factor A signaling in growth restricted fetuses. Molecular and Cellular Endocrinology 435 78-84.

Rozance PJ, Limesand SW \& Hay WW 2006 Decreased nutrientstimulated insulin secretion in chronically hypoglycemic lategestation fetal sheep is due to an intrinsic islet defect. American Journal of Physiology: Endocrinology and Metabolism 291 E404-E411. (doi:10.1152/ajpendo.00643.2005)

Rozance PJ, Limesand SW, Zerbe GO \& Hay WW 2007 Chronic fetal hypoglycemia inhibits the later steps of stimulus-secretion coupling

Published by Bioscientifica Ltd. 
in pancreatic $\beta$-cells. American Journal of Physiology: Endocrinology and Metabolism 292 E1256-E1264. (doi:10.1152/ajpendo.00265.2006)

Rozance PJ, Crispo MM, Barry JS, O'Meara MC, Frost MS, Hansen KC, Hay WW \& Brown LD 2009a Prolonged maternal amino acid infusion in late-gestation pregnant sheep increases fetal amino acid oxidation. American Journal of Physiology: Endocrinology and Metabolism 297 E638-E646. (doi:10.1152/ajpendo.00192.2009)

Rozance PJ, Limesand SW, Barry JS, Brown LD \& Hay WW 2009b Glucose replacement to euglycemia causes hypoxia, acidosis, and decreased insulin secretion in fetal sheep with intrauterine growth restriction. Pediatric Research 65 72-78. (doi:10.1203/PDR.0b013e318189358c)

Rozance PJ, Anderson M, Martinez M, Fahy A, Macko AR, Kailey J, Seedorf GJ, Abman SH, Hay WW \& Limesand SW 2015 Placental insufficiency decreases pancreatic vascularity and disrupts hepatocyte growth factor signaling in the pancreatic islet endothelial cell in fetal sheep. Diabetes 64 555-564. (doi:10.2337/db14-0462)

Satterfield MC, Bazer FW, Spencer TE \& Wu G 2010 Sildenafil citrate treatment enhances amino acid availability in the conceptus and fetal growth in an ovine model of intrauterine growth restriction. Journal of Nutrition 140 251-258. (doi:10.3945/jn.109.114678)

Schuit FC \& Pipeleers DG 1985 Regulation of adenosine 3',5'-monophosphate levels in the pancreatic $\beta$ cell. Endocrinology 117 834-840. (doi:10.1210/endo-117-3-834)

Setia S, Sridhar MG, Bhat V, Chaturvedula L, Vinayagamoorti R \& John M 2006 Insulin sensitivity and insulin secretion at birth in intrauterine growth retarded infants. Pathology 38 236-238. (doi:10.1080/00313020600696256)

Sibley CP, Turner MA, Cetin I, Ayuk P, Boyd CAR, D'Souza SW, Glazier JD, Greenwood SL, Jansson T \& Powell T 2005 Placental phenotypes of intrauterine growth. Pediatric Research 58 827-832. (doi:10.1203/01. PDR.0000181381.82856.23)

Siebel AL, Gallo LA, Guan TC, Owens JA \& Wlodek ME 2010 Crossfostering and improved lactation ameliorates deficits in endocrine pancreatic morphology in growth-restricted adult male rat offspring. Journal of Developmental Origins of Health and Disease $1234-244$. (doi:10.1017/S2040174410000383)

Simmons RA, Templeton LJ \& Gertz SJ 2001 Intrauterine growth retardation leads to the development of Type 2 diabetes in the rat. Diabetes 50 2279-2286. (doi:10.2337/diabetes.50.10.2279)

Snoeck A, Remacle C, Reusens B \& Hoet JJ 1990 Effect of a low protein diet during pregnancy on the fetal rat endocrine pancreas. Neonatology 57 107-118. (doi:10.1159/000243170)

Souza F, Freeby M, Hultman K, Simpson N, Herron A, Witkowsky P, Liu E, Maffei A \& Harris PE 2006 Current progress in non-invasive imaging of beta cell mass of the endocrine pancreas. Current Medicinal Chemistry 13 2761-2773. (doi:10.2174/092986706778521940)

Spégel P, Malmgren S, Sharoyko Vladimir V, Newsholme P, Koeck T \& Mulder H 2011 Metabolomic analyses reveal profound differences in glycolytic and tricarboxylic acid cycle metabolism in glucose-responsive and -unresponsive clonal $\beta$-cell lines. Biochemical Journal 435 277-284.

Speier S, Nyqvist D, Cabrera O, Yu J, Molano RD, Pileggi A, Moede T, Kohler M, Wilbertz J, Leibiger B, et al. 2008 Noninvasive in vivo imaging of pancreatic islet cell biology. Nature Medicine 14 574-578 (doi:10.1038/nm1701)
Steyn LV, Ananthakrishnan K, Anderson MJ, Patek R, Kelly A, Vagner J, Lynch RM \& Limesand SW 2015 A synthetic heterobivalent ligand composed of glucagon-like peptide 1 and yohimbine specifically targets $\beta$ cells within the pancreas. Molecular Imaging and Biology 17 461-470. (doi:10.1007/s11307-014-0817-1)

Stoffers DA 2004 The development of beta-cell mass: recent progress and potential role of GLP-1. Hormone and Metabolic Research 36 811-821. (doi:10.1055/s-2004-826168)

Van Assche FA, Prins FD, Aerts L \& Verjans M 1977 The endocrine pancreas in small-for-dates infants. BJOG 84 751-753. (doi:10.1111/j.1471-0528.1977.tb12486.x)

von Beckerath A-K, Kollmann M, Rotky-Fast C, Karpf E, Lang U \& Klaritsch P 2013 Perinatal complications and long-term neurodevelopmental outcome of infants with intrauterine growth restriction. American Journal of Obstetrics and Gynecology 208130. e131-130.e136.

von Dadelszen P, Dwinnell S, Magee LA, Carleton BC, Gruslin A, Lee B, Lim KI, Liston RM, Miller SP, Rurak D, et al. 2011 Sildenafil citrate therapy for severe early-onset intrauterine growth restriction. BJOG 118 624-628. (doi:10.1111/j.14710528.2010.02879.x)

Wiederkehr A \& Wollheim CB 2012 Mitochondrial signals drive insulin secretion in the pancreatic $\beta$-cell. Molecular and Cellular Endocrinology 353 128-137. (doi:10.1016/j.mce.2011.07.016)

Wigglesworth JS 1964 Experimental growth retardation in the foetal rat. Journal of Pathology and Bacteriology 88 1-13. (doi:10.1002/ path.1700880102)

Willekens S, van der Kroon I, Bos D, Joosten L, Frielink C, Brom M \& Gotthardt M 2015 Quantitative imaging of transplanted pancreatic islets with SPECT using I-123 labeled benzamide. Journal of Nuclear Medicine 56 592. (doi:10.2967/jnumed.112.115097)

Willmann SJ, Mueller NS, Engert S, Sterr M, Burtscher I, Raducanu A, Irmler M, Beckers J, Sass S, Theis FJ, et al. 2016 The global gene expression profile of the secondary transition during pancreatic development. Mechanisms of Development 139 51-64. (doi:10.1016/j. mod.2015.11.004)

Woodall SM, Breier BH, Johnston BM \& Gluckman PD 1996 A model of intra uterine growth retardation caused by chronic maternal undernutrition in the rat: effect of the somatotropic axis and postnatal growth. Journal of Endocrinology 150 231-242. (doi:10.1677/ joe.0.1500231)

Xu G, Stoffers DA, Habener JF \& Bonner-Weir S 1999 Exendin-4 stimulates both beta-cell replication and neogenesis, resulting in increased beta-cell mass and improved glucose tolerance in diabetic rats. Diabetes 48 2270-2276. (doi:10.2337/diabetes.48.12.2270)

Yates DT, Macko AR, Chen X, Green AS, Kelly AC, Anderson MJ, Fowden AL \& Limesand SW 2012 Hypoxaemia-induced catecholamine secretion from adrenal chromaffin cells inhibits glucose-stimulated hyperinsulinaemia in fetal sheep. Journal of Physiology $\mathbf{5 9 0}$ 5439-5447. (doi:10.1113/jphysiol.2012.237347)

Zhang L, Chen W, Dai Y, Zhu Z \& Liu Q 2016 Detection of expressional changes induced by intrauterine growth restriction in the developing rat pancreas. Experimental Biology and Medicine 241 1446-1456. (doi:10.1177/1535370216638771)

Received in final form 27 July 2017

Accepted 10 August 2017

Accepted Preprint published online 14 August 2017 http://joe.endocrinology-journals.org

DOI: 10.1530/JOE-17-0076
๑) 2017 Society for Endocrinology Printed in Great Britain
Published by Bioscientifica Ltd. 